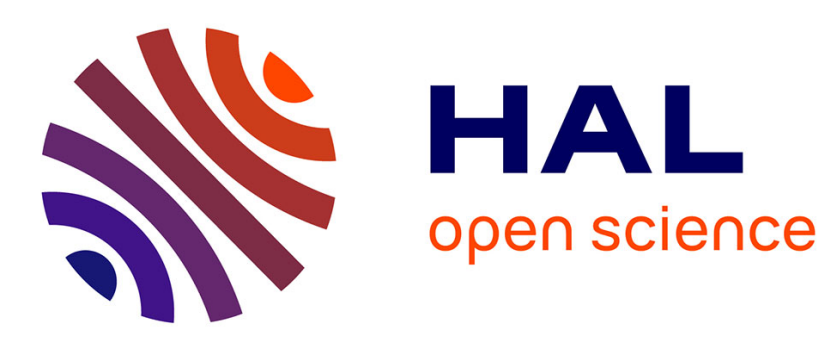

\title{
The Effect of H2S on the Performance of SOFCs using Methane Containing Fuel
}

\author{
Jens F.B. Rasmussen, Anke Hagen
}

\section{To cite this version:}

Jens F.B. Rasmussen, Anke Hagen. The Effect of H2S on the Performance of SOFCs using Methane Containing Fuel. Fuel Cells, 2010, 10 (6), pp.1135. 10.1002/fuce.201000012 . hal-00576976

\section{HAL Id: hal-00576976 https://hal.science/hal-00576976}

Submitted on 16 Mar 2011

HAL is a multi-disciplinary open access archive for the deposit and dissemination of scientific research documents, whether they are published or not. The documents may come from teaching and research institutions in France or abroad, or from public or private research centers.
L'archive ouverte pluridisciplinaire HAL, est destinée au dépôt et à la diffusion de documents scientifiques de niveau recherche, publiés ou non, émanant des établissements d'enseignement et de recherche français ou étrangers, des laboratoires publics ou privés. 


\section{The Effect of $\mathrm{H}_{2} \mathrm{~S}$ on the Performance of SOFCs using Methane Containing Fuel}

\begin{tabular}{|r|l|}
\hline Journal: & Fuel Cells \\
\hline Manuscript ID: & fuce.201000012.R1 \\
\hline Wiley - Manuscript type: & Original Research Paper \\
\hline $\begin{array}{r}\text { Date Submitted by the } \\
\text { Author: }\end{array}$ & 07-Jul-2010 \\
\hline Complete List of Authors: & $\begin{array}{l}\text { Rasmussen, Jens } \\
\text { Hagen, Anke; Risø National Laboratory DTU, Fuel Cells and Solid } \\
\text { State Chemistry Division }\end{array}$ \\
\hline Keywords: & SOFC, hydrogen, sulfide, Methane, Reforming, poisoning \\
\hline \multicolumn{2}{|c}{} \\
\hline
\end{tabular}

\section{s scholaroNE" \\ Manuscript Central}




\title{
The Effect of $\mathrm{H}_{2} \mathrm{~S}$ on the Performance of SOFCs using Methane Containing Fuel
}

J. F. B. Rasmussen ${ }^{1}$, A. Hagen ${ }^{1, *}$

${ }^{1}$ Risø DTU, Fuel Cells and Solid State Chemistry Division, Frederiksborgvej 399, 4000 Roskilde, Denmark [*] Corresponding author: anke@ risoe.dtu.dk, phone: +454677 5884, fax: +45 46775858

\begin{abstract}
In recent years the interest for using biogas derived from biomass as fuel in solid oxide fuel cells (SOFCs) has increased. To maximize the biogas to electrical energy output it is important to study the effects of the main biogas components $\left(\mathrm{CH}_{4}\right.$ and $\left.\mathrm{CO}_{2}\right)$, minor ones and traces (e.g. $\left.\mathrm{H}_{2} \mathrm{~S}\right)$ on performance and durability of the SOFC. Single anode-supported SOFCs with Ni-YSZ anodes, YSZ electrolytes and LSM-YSZ cathodes have been tested with a $\mathrm{CH}_{4}-\mathrm{H}_{2} \mathrm{O}-\mathrm{H}_{2}$ fuel mixture at $\mathrm{OCV}$ and $1 \mathrm{Acm}^{-2}$ current load $\left(850^{\circ} \mathrm{C}\right)$. The cell performance

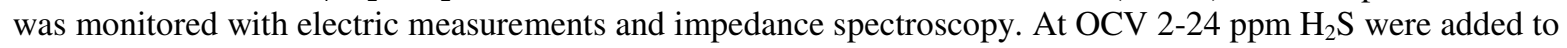
the fuel in $24 \mathrm{~h}$ intervals. The reforming activity of the Ni-containing anode decreased rapidly when $\mathrm{H}_{2} \mathrm{~S}$ was added to the fuel. This ultimately resulted in a lower production of fuel $\left(\mathrm{H}_{2}\right.$ and $\left.\mathrm{CO}\right)$ from $\mathrm{CH}_{4}$. Applying $1 \mathrm{Acm}^{-}$ ${ }^{2}$ current load, a maximum concentration of $7 \mathrm{ppm} \mathrm{H}_{2} \mathrm{~S}$ was acceptable for a $24 \mathrm{~h}$ period.
\end{abstract}

\section{Keywords}

hydrogen sulfide, methane reforming, poisoning, SOFC.

\section{Introduction}

Technological solid oxide fuel cells (SOFCs) have been demonstrated to operate very well when running on $\mathrm{H}_{2}$, synthesis gas or $\mathrm{CH}_{4}$-containing fuels for long operation times (e.g., [1]). It has thus become interesting to study the applicability of alternative fuel sources, like biogas derived from biomass. Biogas produced by anaerobic digestion of biomass mainly consists of $\mathrm{CH}_{4}$ and $\mathrm{CO}_{2}$, but also small amounts of impurities, such as for example $\mathrm{H}_{2} \mathrm{~S}(>30 \mathrm{ppm})$, halogens, and siloxanes. At the high operational temperature of SOFCs $\left(700-900^{\circ} \mathrm{C}\right)$ and the presence of Ni-catalyst electrodes, the main components $\mathrm{CH}_{4}, \mathrm{CO}_{2}$ and $\mathrm{H}_{2} \mathrm{O}$ are converted to $\mathrm{H}_{2}$ and $\mathrm{CO}$ (Reaction (1)).

$$
\text { (1) } 2 \mathrm{CH}_{4}+\mathrm{CO}_{2}+\mathrm{H}_{2} \mathrm{O} \rightarrow 5 \mathrm{H}_{2}+3 \mathrm{CO}
$$

As both $\mathrm{H}_{2}$ and $\mathrm{CO}$ are fuels to the SOFC the use of biogas in SOFCs seems very attractive. However, the effect of the fuel on performance and durability has to be studied; specifically the main constituents methane vs. hydrogen and impurities such as $\mathrm{H}_{2} \mathrm{~S}$.

$\mathrm{CH}_{4}$-containing fuels in Ni-YSZ anode based $\mathrm{SOFCs}$ have been investigated using oxygen-species $\mathrm{O}_{2}, \mathrm{H}_{2} \mathrm{O}$ and/or $\mathrm{CO}_{2}$, to convert $\mathrm{CH}_{4}$ with the $\mathrm{Ni}$ in the anode acting as catalyst [2-8]. A critical issue in these studies has been the conversion of $\mathrm{CH}_{4}$ on the anode's $\mathrm{Ni}$ particles without producing coke, as coke lowers the performance of an SOFC. The coke formation can be controlled by different factors, for example the operational temperature and the $\mathrm{O}: \mathrm{C}$ ratio. A large part of the studies has thus included varying the operational temperature and the $\mathrm{O}: \mathrm{C}$ ratio to find out how these parameters affect SOFC performance. Typically, increasing the oxygen-species concentration decreases the coke formation, but leads to a decrease in the SOFC efficiency as the oxygen-species dilute the fuel. Furthermore, the Ni particles risk being oxidised at high oxygen-species concentrations in the fuel [9]. It is thus necessary to optimize the fuel component concentrations and the operational temperature to optimize the SOFC performance.

Special attention has been given to the steam reforming of methane, in particular due to the close relations between the typical nickel containing steam reforming catalyst and the nickel containing SOFC anode. In the steam reforming of $\mathrm{CH}_{4}$, three main reactions occur, i.e. the steam reforming reaction (Reaction (2)), the water gas shift reaction (Reaction (3)) and the methanation reaction (Reaction (4)):

(2) $\mathrm{C}_{n} \mathrm{H}_{m}+n \mathrm{H}_{2} \mathrm{O} \rightarrow n \mathrm{CO}+\left(n+\frac{m}{2}\right) \mathrm{H}_{2}$

(3) $\mathrm{CO}+\mathrm{H}_{2} \mathrm{O} \leftrightarrow \mathrm{CO}_{2}+\mathrm{H}_{2}$

(4) $\mathrm{CO}+3 \mathrm{H}_{2} \rightarrow \mathrm{CH}_{4}+\mathrm{H}_{2} \mathrm{O}$ 
Having a steam to carbon ratio of 2 at typical SOFC operational temperature $\left(\sim 800^{\circ} \mathrm{C}\right)$ is considered to prevent coke formation [10].

Impurities like $\mathrm{H}_{2} \mathrm{~S}$ in the fuel are critical. From catalysis it is also known that sulphur poisons the reforming activity of Ni-based catalysts and the underlying mechanism is fairly well understood [11]. The natural gas (methane) is usually desulphurized prior to the reforming process in order to prevent the reforming catalyst from being poisoned. Also in the SOFC, $\mathrm{H}_{2} \mathrm{~S}$ naturally affects the reforming, as a nickel containing anode is used, and the electrochemical activity as well [10].

Several research groups have experimentally studied the effect of having S-compounds in an $\mathrm{H}_{2}$-containing fuel on the performance and the durability of an SOFC [12-14], but also the effect of S-compounds in $\mathrm{CH}_{4}-$ containing fuels $[15,16]$ has been studied. It was shown that $\mathrm{H}_{2} \mathrm{~S}$ had a significant effect on the reforming activity, which in this way also affected the power output of the SOFCs. It has to be noted that the studies were performed in fuel with very low methane concentrations ([15]: catalytic partial oxidation (CPO) gas with 1.5 vol\% $\mathrm{CH}_{4}$, [16]: natural gas reformate) and that the direct use of biogas poses a larger challenge due to the high concentrations. It was also concluded that the $\mathrm{Ni}$-sites active for reforming were different from the sites active for the electrochemical reaction [15]. Summarizing, when using biogas as fuel in an SOFC, two effects of $\mathrm{H}_{2} \mathrm{~S}$ have to be considered: Poisoning of the reforming and of electrochemical activity and the interplay between these.

In a former study [13], the effect of $\mathrm{H}_{2} \mathrm{~S}$ on the electrochemical activity (performance) of a SOFC using an $\mathrm{H}_{2}-$ $\mathrm{H}_{2} \mathrm{O}$ gas mixture was evaluated. In the current study $\mathrm{CH}_{4}$ was included in the fuel and thus the aspect of poisoning of reforming activity introduced. Varying concentrations of $\mathrm{H}_{2} \mathrm{~S}$ were added at intervals. Electrical measurements and impedance spectroscopy were used to monitor the effect of S-poisoning on the cell voltage and the internal resistance of the SOFCs. Mass spectrometry was used to monitor the steam reforming activity of $\mathrm{CH}_{4}$ as a function of the $\mathrm{H}_{2} \mathrm{~S}$ concentration. This gave the possibility to study the effect of $\mathrm{H}_{2} \mathrm{~S}$ on both the electrochemistry and the reforming activity.

\section{Experimental}

\subsection{Cells and Initial Electrochemical Characterization}

The used planar SOFCs were produced at the pre-pilot facility located Ris $\phi$ DTU and had a Ni/Yttria-StabilizedZirconia (Ni/YSZ) anode support and an active Ni/YSZ anode, a YSZ electrolyte, and a Lanthanum-StrontiumManganate (LSM)/YSZ cathode [17]. The active area was $4 \times 4 \mathrm{~cm}^{2}$ (total area of $5 \times 5 \mathrm{~cm}^{2}$ ). In the testing setup the cells were placed between Ni containing anode and LSM containing cathode gas distribution layers, and secondly, between current collector foils, i.e. a $\mathrm{Ni}$ foil on the anode side and an $\mathrm{Au}$ foil on the cathode side. The setup was sealed using glass/ceramic-composite bars. A more detailed description of the setup can be found in [18].

The tests were started by sealing and reducing the cells at $1000{ }^{\circ} \mathrm{C}$ followed by an initial electrochemical characterisation (fingerprint) at 850,800 and $750{ }^{\circ} \mathrm{C}$ to verify that the cell performances were as expected. The fingerprint measurements comprised of $\mathrm{iV}$-curves and impedance spectra in $96 \% \mathrm{H}_{2}+4 \% \mathrm{H}_{2} \mathrm{O}$ and $80 \% \mathrm{H}_{2}+$ $20 \% \mathrm{H}_{2} \mathrm{O}$ fuel composition. In the impedance measurements an oscillating current of approximately $60 \mathrm{~mA}$ was applied over the frequency range $0.08 \mathrm{~Hz}$ to $82 \mathrm{kHz}$ with a Solartron impedance analyser.

\subsection{Cell Testing}

In Figure 1 the setup for single cell testing in different fuels is illustrated. The fuel gases $\left(\mathrm{H}_{2}, \mathrm{CH}_{4}\right.$ and $\left.\mathrm{O}_{2}\right)$ were supplied through mass flow controllers. Firstly, the $\mathrm{H}_{2}$ and $\mathrm{O}_{2}\left(p \mathrm{H}_{2}>p \mathrm{O}_{2}\right)$ were mixed, this way forming an $\mathrm{H}_{2} / \mathrm{H}_{2} \mathrm{O}$ gas mixture. Additionally, the $\mathrm{H}_{2}$ could be moisturized in a water bottle $\left(\sim 4 \% \mathrm{H}_{2} \mathrm{O}\right)$ before mixing with $\mathrm{O}_{2} . \mathrm{H}_{2} \mathrm{~S}$ from a pressurised $\mathrm{H}_{2} \mathrm{~S} / \mathrm{H}_{2}$-bottle containing $218 \mathrm{ppm} \mathrm{H}_{2} \mathrm{~S}$ was mixed with the $\mathrm{CH}_{4}$. The thus obtained two mixtures were combined and led into the cell test house. The total fuel flow at the cell inlet was kept constant at $10 \mathrm{lh}^{-1}$. Air was used on the cathode side $\left(140 \mathrm{lh}^{-1}\right)$.

Two different test series were carried out. The aim of the first test series was to measure the effect of $\mathrm{H}_{2} \mathrm{~S}$ on the reforming activity in the anode. An SOFC was run at OCV with a quadrupole mass spectrometer (QMS) attached to the fuel inlet and outlet tubes. This way the changes in gas composition as a function of the $\mathrm{H}_{2} \mathrm{~S}$ concentration were monitored. In this test series the $\mathrm{H}_{2} \mathrm{~S}$ was added in steps for periods of 25-75 h (illustrated in $A$ on the right-hand side of Figure 1).

The second series of tests involved measuring the effect of $\mathrm{H}_{2} \mathrm{~S}$ on the performance of the SOFCs. Three SOFCs were run under current load. Illustration $B$ on the right-hand side of Figure 1 shows how $\mathrm{H}_{2} \mathrm{~S}$ was added with increasing concentrations for $24 \mathrm{~h}$ intervals. 


\section{Figure 1}

The test setup included temperature, current and voltage probes. Furthermore, $p \mathrm{O}_{2}$ probes were placed in the fuel inlet and outlet tubes to measure the oxygen partial pressure by measuring voltages $\left(p \mathrm{O}_{2}\right.$-in voltage and $p \mathrm{O}_{2}$-out voltage, respectively). The $p \mathrm{O}_{2}$ probes were made of single ended zirconia based tubes, and were supplied with a constant flow of air on the inside. Two Pt wires (one on the inside and one on the outside of the tube) measure the potential difference across the tube wall. By using the Nernst equation the partial pressure of oxygen on the outside (the fuel inlet or outlet) was calculated. A third $\mathrm{Pt} / \mathrm{Rh}$ wire was welded together with the inside $\mathrm{Pt}$ wire, and was used to measured the inlet and outlet fuel temperature. The SOFC performance was evaluated by measuring the cell voltage, the in-plane voltage in anode and cathode (Figure 1) as well as by impedance spectroscopy (see also [13]).

\subsection{Mass Spectrometry}

An OmniStar ${ }^{\mathrm{TM}}$ GSD 30101 quadrupole mass spectrometer (QMS) from Pfeiffer Vacuum was used. It was equipped with an approximately $1 \mathrm{~m}$ long stainless steel capillary $(\varnothing 0.12 \mathrm{~mm})$. The capillary was heated by a heating tape and was connected to the cell house fuel tubes via a $\sim 30 \mathrm{~cm}$ long stainless steel tube with $\varnothing 5 \mathrm{~mm}$. Both transfer lines between the cell testing setup and the QMS were heated $\left(>100^{\circ} \mathrm{C}\right)$.

\section{Results and Discussion}

\subsection{Steam Reforming Activity of the Ni-YSZ Anode}

The first test series was carried out to study the effect of $\mathrm{H}_{2} \mathrm{~S}$ on the catalytic activity of the Ni/YSZ-anode in an SOFC for the steam reforming. The measurements were carried out at $850^{\circ} \mathrm{C}$ with a fuel composition of $13 \% \mathrm{H}_{2}$, $29 \% \mathrm{CH}_{4}$ and $58 \% \mathrm{H}_{2} \mathrm{O}$. The total fuel flow was $10 \mathrm{lh}^{-1}$. The measured OCV under these $\mathrm{S}$-free conditions was $984 \mathrm{mV}$, the $p \mathrm{O}_{2}$-in voltage $850 \mathrm{mV}$ and the $p \mathrm{O}_{2}$-out voltage $980 \mathrm{mV}$. These three voltage values can be directly translated to fuel compositions and were used to evaluate the tightness of the testing setup and the reforming activity.

The theoretical cell voltage $(E m f)$ for the SOFC for the present gas mixture was calculated to be $\sim 995 \mathrm{mV}$. We consider an SOFC to have a gas tight electrolyte and to be sealed sufficiently gas tight from the surroundings if the voltage values do not differ from the Emf by more than approximately $10-15 \mathrm{mV}$. This demand was fulfilled with the obtained $p \mathrm{O}_{2}$-out of $980 \mathrm{mV}$. We can thus conclude the setup to be sufficiently tight and the influence of leaking gases on the fuel composition and thus mass spectrometry analysis to be negligible.

The OCV and $p \mathrm{O}_{2}$-out values of 984 and $980 \mathrm{mV}$, respectively, correspond to the equilibrium gas mixture, when steam reforming has occurred (Emf: $995 \mathrm{mV}$ ). The $p \mathrm{O}_{2}$-in at the fuel inlet was smaller, which means that the hydrogen concentration in the fuel before entering the SOFC was lower than under the equilibrium conditions, i.e. the reforming reaction had not taken place before the fuel had contacted the SOFC anode. This finding was expected as it is known that reforming does not proceed spontaneously but needs a catalyst. The cell voltage (OCV) and the $p \mathrm{O}_{2}$-out on the other hand were the same and corresponded to the equilibrium gas composition of the reformed fuel. Therefore, reforming happened quite fast after the first contact of the methane containing fuel with the SOFC anode (in absence of $\mathrm{H}_{2} \mathrm{~S}$ ).

To monitor the effect of $\mathrm{H}_{2} \mathrm{~S}$ on the steam reforming activity in the anode, the $\mathrm{H}_{2} \mathrm{~S}$ was added in steps of increasing concentration from $2 \mathrm{ppm}$ to $24 \mathrm{ppm}$. After adding the $\mathrm{H}_{2} \mathrm{~S}$ to the fuel, the cell voltage initially dropped fast and then an almost constant cell voltage about $25-75 \mathrm{~h}$ after adding the $\mathrm{H}_{2} \mathrm{~S}$ was reached. At each of these constant periods iV-curves were measured. The cell voltage development is shown in Figure 2. The measured cell voltages at each step were: $984 \mathrm{mV}(0 \mathrm{ppm}), 949 \mathrm{mV}(2 \mathrm{ppm}), 921 \mathrm{mV}(4 \mathrm{ppm}), 910 \mathrm{mV}$ (7 ppm), $902 \mathrm{mV}(9 \mathrm{ppm}), 885 \mathrm{mV}(20 \mathrm{ppm})$ and $882 \mathrm{mV}$ (24 ppm) (see also Figure 2). As the $\mathrm{H}_{2} \mathrm{~S}$ was turned off, the cell voltage returned to a similar level as before adding the $\mathrm{H}_{2} \mathrm{~S}$.

\section{Figure 2}

As the fuel composition was only changed to a small extent (ppm amounts of $\mathrm{H}_{2} \mathrm{~S}$ were added), this drop of the cell voltage cannot be related to the $\mathrm{H}_{2} \mathrm{~S}$ concentrations in the fuel but indicates a significantly changed fuel composition regarding the other components, i.e. the steam reforming reaction was affected and the fuel composition gradually changed towards the initial fuel inlet composition $\left(850 \mathrm{mV}, p \mathrm{O}_{2}\right.$-in) when increasing the $\mathrm{H}_{2} \mathrm{~S}$ concentrations. The drop in OCV was thus a direct effect of $\mathrm{S}$ chemisorbed on the active sites for the methane reforming. 
Simultaneously to the voltage measurements under addition of $\mathrm{H}_{2} \mathrm{~S}$, also the gas composition was measured at the fuel outlet using mass spectrometry. In steam reforming, the main reactions (2)-(4) proceed, i.e. an increased amount of $\mathrm{CO}$ and $\mathrm{CO}_{2}$ in the fuel can be directly related to the converted $\mathrm{CH}_{4}$.

At the times of constant cell voltage during addition of $\mathrm{H}_{2} \mathrm{~S}$, the fuel gas composition was analysed using the QMS. In Figure 3 the relative ratios of the measured $\mathrm{CO}, \mathrm{CO}_{2}$ and $\mathrm{CO}+\mathrm{CO}_{2}$ intensities (reaction products, see Equation (2)-(3)) to the $\mathrm{CH}_{4}$ intensity (reactant, see Equation (1)) are shown. To avoid having to correct for small pressure differences (and thus differences in absolute intensities) between the single QMS measurements, only ratios of the intensities have been considered. The ratios between product/reactant decreased first rapidly when between 0 ppm and 4 ppm $\mathrm{H}_{2} \mathrm{~S}$ were added. At $4 \mathrm{ppm}$ the ratios had dropped by $\sim 90 \%$. This indicated that the steam reforming of $\mathrm{CH}_{4}$ was strongly affected even at a low $\mathrm{H}_{2} \mathrm{~S}$ concentration. With further increasing the $\mathrm{H}_{2} \mathrm{~S}$ concentration, this ratio decreased slower.

\section{Figure 3}

Based on the measured cell voltage values under $\mathrm{H}_{2} \mathrm{~S}$, the fuel gas composition in the cell was calculated using a program developed in house. In Figure 4 the thus calculated $\mathrm{CH}_{4}$ conversion is plotted as a function of the $\mathrm{H}_{2} \mathrm{~S}$ concentration. Even low concentrations of $\mathrm{H}_{2} \mathrm{~S}$ in the fuel (2-4 ppm) have a large effect on the steam reforming activity of the SOFC anode, thereby confirming the observed inhibition of reforming as measured by the QMS (see Figure 3). At 24 ppm $\mathrm{H}_{2} \mathrm{~S}$ less than $15 \%$ of the $\mathrm{CH}_{4}$ in the fuel is converted.

Rostrup-Nielsen [19] published a relation between the coverage of $\mathrm{S}$ on a Ni catalyst, $\theta_{S}$, , the temperature $T$ in Kelvin and the ratio between the partial pressures of $\mathrm{H}_{2} \mathrm{~S}$ and $\mathrm{H}_{2}, Y=p \mathrm{H}_{2} \mathrm{~S} / p \mathrm{H}_{2}$ (equation (5))

$$
\text { (5) } \theta_{s}=1.45-9.53 \cdot 10^{-5} \cdot T+4.17 \cdot 10^{-5} \cdot T \cdot \ln (Y)
$$

When applying the $p \mathrm{H}_{2} \mathrm{~S}$ and $p \mathrm{H}_{2}$ values used in our $\mathrm{CH}_{4}$ tests, $\theta_{s}$ becomes 0.86 at $850^{\circ} \mathrm{C}$ and $4 \mathrm{ppm} \mathrm{H}_{2} \mathrm{~S}$ (see insert in Figure 4). Having covered the active sites to such a large extent, the observed rapid poisoning of the $\mathrm{CH}_{4}$ reforming seems quite reasonable.

\section{Figure 4}

\subsection{SOFC Performance}

The first test series discussed above was aimed at studying the effect of $\mathrm{H}_{2} \mathrm{~S}$ at OCV and reflected thus purely catalytic activity and poisoning. However, current might have a significant effect. Among others Koh et al. [20] found that less coke was formed on an SOFC under current load compared to an SOFC at OCV. It was speculated that the coke was being reacted off the Ni particles at the three-phase-boundaries (TPB) by $\mathrm{O}^{2-}$-ions. $\mathrm{O}^{2-}$-ions have also been suggested to facilitate desorption of $\mathrm{S}$ species from the TPB [14, 15, 21]. The degree of poisoning of the $\mathrm{CH}_{4}$ conversion might be moderated when the SOFC is in use, i.e. under current load.

Three SOFCs were tested under current load $\left(1 \mathrm{Acm}^{-2}\right)$ in $\mathrm{CH}_{4}$-containing fuel and were exposed to $\mathrm{H}_{2} \mathrm{~S}$ for $24 \mathrm{~h}$ intervals in order to study the effect of $\mathrm{H}_{2} \mathrm{~S}$ on the steam reforming activity and electrochemistry. In all three tests a steam to carbon ratio of $\sim 2: 1$ was used to prevent coke formation on the Ni particles. The tests were run at a temperature of $850^{\circ} \mathrm{C}$. In test 1 , a smaller $\mathrm{CH}_{4}$ concentration was used than in test 2 and 3 , in order to study the importance of $\mathrm{CH}_{4}$ concentration. The fuel compositions, the fuel utilization $(F U)$ and the initial area specific resistance values corrected for $F U\left(A S R_{\text {cor }}\right)$ [18] of the cells in test 1-3 (denoted $\mathrm{CH}_{4}$ tests) are shown in Table 1.

\section{Table 1}

The cell voltage developments are shown in Figure 5. After turning on the current load, the SOFCs were run in the $\mathrm{CH}_{4} / \mathrm{H}_{2} / \mathrm{H}_{2} \mathrm{O}$ fuel for 300-500 h before adding the first portion of $\mathrm{H}_{2} \mathrm{~S}$. During this period each of the cells degraded (50-60 $\mathrm{mV}$ per $1000 \mathrm{~h}$ ). Addition of $\mathrm{H}_{2} \mathrm{~S}$ to the fuel resulted in an initial voltage drop, followed by a nearly constant cell voltage degradation. After turning off the $\mathrm{H}_{2} \mathrm{~S}$ the cell voltage regenerated to a level consistent with the overall degradation observed in the absence of $\mathrm{H}_{2} \mathrm{~S}$. The insert in Figure 5 shows these effects after adding the $4 \mathrm{ppm}_{2} \mathrm{~S}$ to the fuel in test 1 as example. In test 2 and 3, the current load was interrupted for $\sim 100 \mathrm{~h}$ due to work on the lab facilities. These interruptions (indicated by horizontal arrows) did not affect the overall cell voltage development.

The cell voltage development had thus much similar characteristics as in the poisoning tests in $\mathrm{H}_{2}$ fuel [13]. The first voltage drop was ascribed a fast adsorption of $\mathrm{S}$ on the Ni surface, blocking the active sites for hydrogen 
adsorption and oxidation $[13,14]$. The reason for the following voltage degradation is not completely clear at the moment.

During regeneration from $2 \mathrm{ppm}$ (second time) in test 1, the cell voltage did not return entirely to the overall voltage development, but instead started to decrease progressively. The test was stopped, when a critical cell voltage was reached. When adding $9 \mathrm{ppm}_{2} \mathrm{~S}$ in test 3 the cell voltage dropped rapidly below $450 \mathrm{mV}$, which resulted in an automatic turn off of current (cell voltage set to OCV by the system, see vertical arrow in Figure 5). After stopping the $\mathrm{H}_{2} \mathrm{~S}$ addition and turning on the current load again, the cell voltage regenerated to a level consistent with the overall development. Adding $7 \mathrm{ppm}_{2} \mathrm{~S}$ also resulted in a rapid, large voltage drop below $450 \mathrm{mV}$, which again triggered the system to turn off the current (OCV). Afterwards, it was not possible to apply the same current load $\left(1 \mathrm{Acm}^{-2}\right)$ and the test was stopped.

Therefore the maximum $\mathrm{H}_{2} \mathrm{~S}$ amount, which can be allowed in the $\mathrm{CH}_{4}$-containing fuels during a $24 \mathrm{~h}$ time period under the present conditions, is around/below 7 to $9 \mathrm{ppm}$. Taking the $\mathrm{CH}_{4}$ conversion determined at OCV as a guideline (see section above and Figure 4) only 20-30\% of the $\mathrm{CH}_{4}$ was converted at these $\mathrm{H}_{2} \mathrm{~S}$ concentrations. As a consequence, the fuel gas in the cell should contain less $\mathrm{CO}$ and $\mathrm{H}_{2}$ and more methane.

During the three tests the $p \mathrm{O}_{2}$-in voltage and -out voltage were monitored in order to gather information about the gas compositions entering into and leaving the SOFC. They were both constant except for $p \mathrm{O}_{2}$-out in the cases when $4 \mathrm{ppm}$ and $7 \mathrm{ppm} \mathrm{H}_{2} \mathrm{~S}$ were added in test 1 , and when $4 \mathrm{ppm}$ and $9 \mathrm{ppm}_{2} \mathrm{~S}$ were added in test 3 .

In test 1 the $p \mathrm{O}_{2}$-out voltage dropped by $15 \mathrm{mV} \pm 5 \mathrm{mV}$ when 4 ppm was added and by $32 \mathrm{mV} \pm 5 \mathrm{mV}$ when 7 ppm was added. In test 3 the $p \mathrm{O}_{2}$-out voltage dropped by $18 \mathrm{mV} \pm 2 \mathrm{mV}$ when $4 \mathrm{ppm} \mathrm{H}_{2} \mathrm{~S}$ was added. It was not possible to determine how much the $p \mathrm{O}_{2}$-out voltage dropped at $9 \mathrm{ppm}$ as the current was stopped almost immediately. The $p \mathrm{O}_{2}$-in voltage remained constant in all three tests as expected, because the fuel gas flows and thus the gas compositions entering the cells were kept constant. The drop of the $p \mathrm{O}_{2}$-out voltage at the large $\mathrm{H}_{2} \mathrm{~S}$ concentrations is thus a result of the lower concentrations of $\mathrm{H}_{2}$ and $\mathrm{CO}$ in the fuel outlet gas due to a smaller $\mathrm{CH}_{4}$ conversion, a direct consequence of the decreased reforming activity of the anode.

\section{Figure 5}

A lower production of these fuels would also affect the fuel utilization, which might reach values critical for the SOFC anode. The fuel utilization in these cases of strong poisoning was therefore calculated using the gas compositions determined during $\mathrm{H}_{2} \mathrm{~S}$ poisoning tests at OCV (see Figure 6).

Indeed, adding $7 \mathrm{ppm}$ and $9 \mathrm{ppm} \mathrm{H}_{2} \mathrm{~S}$ in test 3 resulted in a $F U>90 \%$, i.e. all of the initially added $\mathrm{H}_{2}$ and a small amount of $\mathrm{H}_{2}+\mathrm{CO}$ from the remaining steam reforming reaction of $\mathrm{CH}_{4}$ were converted in the electrochemical reaction. Operating the cells at these large $F U$ s resulted in very low concentrations of $\mathrm{H}_{2}$ and $\mathrm{CO}$ as measured near the outlet part of the cells, which can result in oxidation of the Ni particles (Ni particles become oxidised by $\mathrm{O}^{2-}$-ions from the cathode). This explains the rapid voltage drop below $450 \mathrm{mV}$ in test 3 , when 9 ppm $\mathrm{H}_{2} \mathrm{~S}$ were added. A larger amount of $\mathrm{H}_{2}$ in the initial fuel can counteract such over-critical $F U \mathrm{~s}$. A gradual poisoning of the $\mathrm{CH}_{4}$ reforming and thus smaller supply of $\mathrm{H}_{2}$ and $\mathrm{CO}$ has then a less severe effect (see test 1).

\section{Figure 6}

During poisoning tests in $\mathrm{H}_{2}$ fuel, a clear correlation between the initial cell voltage drop and the $\mathrm{H}_{2} \mathrm{~S}$ concentration was found [13]. This parameter was also analysed for the $\mathrm{CH}_{4}$ tests in this study. In Table 2 the initial voltage drops $\left(\Delta V_{i n i}\right)$ for the cells in the $\mathrm{CH}_{4}$ tests and for an SOFC with the same test parameters, but running on fuel consisting of only $\mathrm{H}_{2}$ and $\mathrm{H}_{2} \mathrm{O}$ (referred to as $\mathrm{H}_{2}$ test [13]), are listed as a function of the $\mathrm{H}_{2} \mathrm{~S}$ concentration. At low $\mathrm{H}_{2} \mathrm{~S}$ concentration $\left(2 \mathrm{ppm} \mathrm{H}_{2} \mathrm{~S}\right.$ ) the initial voltage drops were approximately the same for the cells in the $\mathrm{CH}_{4}$ tests 1 and 2 (present study) as for the $\mathrm{H}_{2}$ test [13]. At higher $\mathrm{H}_{2} \mathrm{~S}$ concentrations the cells in the $\mathrm{CH}_{4}$ tests started to experience a larger initial voltage drop than in the $\mathrm{H}_{2}$ test.

After the initial voltage drop the SOFCs degraded (more than the overall cell voltage degradation). In Table 2 the degradation rates $\left(\tau_{d e g}\right)$ are listed as a function of the $\mathrm{H}_{2} \mathrm{~S}$ concentration.

Table 2 
Analysing the degradation rates under $\mathrm{H}_{2} \mathrm{~S}$ exposure, the $\mathrm{CH}_{4}$ tests show much larger rates at comparable $\mathrm{H}_{2} \mathrm{~S}$ concentrations (Table 2). These results suggest that the effects of S-poisoning on SOFCs fuelled with $\mathrm{CH}_{4}$ containing gases are much more severe. From investigations of steam reforming catalysts it was concluded that steam reforming primarily happens at the defect sites (steps), which are also the preferred adsorption sites for $\mathrm{S}$ [22]. The electrochemical oxidation of $\mathrm{H}_{2}$ is less site-sensitive. The S-poisoning effects are thus more significant for the tests with $\mathrm{CH}_{4}$-containing fuels, because of the sensitive steam reforming reaction.

After stopping the $\mathrm{H}_{2} \mathrm{~S}$ addition, the cell voltage regenerated slowly (Figure 5). The poisoning reflected by the drop pf cell voltage occurred within $\sim 24 \mathrm{~h}$, while the whole recovery occurred over $\sim 200 \mathrm{~h}$ in both the $\mathrm{CH}_{4}$ tests and in the $\mathrm{H}_{2}$ test [13]. The entire poisoning was thus faster than the entire recovery (see Figure 5). A way to quantify the poisoning and recovery rates is to determine the times for $50 \%$ change, i.e. $50 \%$ initial voltage drop compared to $50 \%$ voltage recovery.

In Figure 7 the rates of the initial poisoning rates (50\% voltage drop) and initial recovery rates (50\% voltage increase) in the $\mathrm{CH}_{4}$ tests (top figure) and in the $\mathrm{H}_{2}$ test [13] (bottom figure) are plotted. In the $\mathrm{CH}_{4}$ tests the initial poisoning and initial recovery rates were almost the same over the used concentration range, while there was a difference in the $\mathrm{H}_{2}$ test; the initial poisoning rate was larger than the initial recovery rate (see Figure 7). This difference increased with $\mathrm{H}_{2} \mathrm{~S}$ concentration (10 times larger at $100 \mathrm{ppm} \mathrm{H}_{2} \mathrm{~S}$ ).

\section{Figure 7}

Comparing the $\mathrm{CH}_{4}$ tests and the $\mathrm{H}_{2}$ test, the initial poisoning rates were almost the same in these, while the initial recovery rate for the test in $\mathrm{H}_{2}$ was much smaller. This result points to different recovery mechanisms depending on the fuel. Assuming the recovery to be due to desorption of S-species from the Ni particles in the SOFC anode, this process can be in general facilitated by an increase of temperature, a decrease of the pressure or by addition of a displacement agent. The faster recovery in the $\mathrm{CH}_{4}$ tests could thus be explained by the presence of a higher $\mathrm{H}_{2} \mathrm{O}$ concentration in the fuel in the $\mathrm{CH}_{4}$ tests, $\mathrm{H}_{2} \mathrm{O}$ acting as an efficient displacement agent.

Impedance spectroscopy was used to obtain more detailed information about the effect of $\mathrm{H}_{2} \mathrm{~S}$ on the cells internal resistances. This was done by measuring the impedance of the SOFCs before, during and after each $\mathrm{H}_{2} \mathrm{~S}$ cycle. To determine the most relevant times for recording impedance spectra the anode in-plane voltages were followed and impedance spectra were taken at the times of constant levels [13]. In test 1 it was not possible to achieve acceptable resolution on the low frequency part of the spectra $(<\sim 10 \mathrm{~Hz})$, due to small cell voltage oscillations. However, the development of the high frequency arc showed similar development during the poisoning cycles for all the $\mathrm{CH}_{4}$ tests. The case of $2 \mathrm{ppm} \mathrm{H}_{2} \mathrm{~S}$ addition in test 2 is shown in Figure 8 as an example. The Nyquist plots show that the total internal resistance of the cell increased as $\mathrm{H}_{2} \mathrm{~S}$ was added to the fuel until the cell was at steady state (the constant level in the in-plane voltage indicates steady state: $\triangle$ in the insert). But it returned nearly to the initial level when the $\mathrm{H}_{2} \mathrm{~S}$ addition was stopped. The serial resistance increased minimally during the interval $\left(<0.02 \Omega \mathrm{cm}^{2}\right)$, which was consistent with the overall degradation of the cell voltage. As the cell voltages degraded in the $\mathrm{CH}_{4}$ tests even before the first $\mathrm{H}_{2} \mathrm{~S}$ addition, this increase in series resistance is assigned to the overall voltage degradation. The reason for the overall cell voltage degradation might be related to coke formation on the Ni particles, even though a steam to carbon ratio of 2 was applied.

Mainly the polarization resistance changed under addition of $\mathrm{H}_{2} \mathrm{~S}$. From Figure 8 it can be concluded that the polarization resistance increase was reversible and that mainly the high frequency arc increased. These results thus coincide with those obtained during $\mathrm{H}_{2} \mathrm{~S}$ poisoning in $\mathrm{H}_{2}$-fuel, although at much smaller $\mathrm{H}_{2} \mathrm{~S}$-concentrations $[13]$.

\section{Figure 8}

\section{Conclusions}

It was studied, how $\mathrm{H}_{2} \mathrm{~S}$ affects the reforming and electrochemical activity of a Ni/YSZ anode in a technological SOFC by adding $\mathrm{H}_{2} \mathrm{~S}$ to a $\mathrm{CH}_{4}$-containing fuel. It was found that $\mathrm{H}_{2} \mathrm{~S}$ had a larger effect on the reforming activity than on the electrochemical activity. At 4 ppm $\mathrm{H}_{2} \mathrm{~S}$ addition, more than $60 \%$ of the reforming activity was eliminated at $\mathrm{OCV}$, which meant that the production of fuel $\left(\mathrm{H}_{2}\right.$ and $\left.\mathrm{CO}\right)$ was diminished significantly. When operating an SOFC under current load a maximum $\mathrm{H}_{2} \mathrm{~S}$ concentration just below 7-9 ppm was acceptable during a $24 \mathrm{~h}$ period. At these $\mathrm{H}_{2} \mathrm{~S}$ concentrations the production of $\mathrm{CO}$ and $\mathrm{H}_{2}$ fuel from steam reforming was 
suppressed to a large extent. If not additional hydrogen is added to the fuel, a critical fuel utilization and thus oxidation of the Ni particles leading to a severe degradation of the cell voltage might occur.

The poisoning of the electrochemical activity proceeded similarly in methane and hydrogen fuel. The recovery of the cell voltage after stopping the $\mathrm{H}_{2} \mathrm{~S}$ exposure was accelerated in the methane/steam containing fuel. Probably, steam facilitates efficient desorption of $\mathrm{S}$ from $\mathrm{Ni}$-sites.

\section{Acknowledgement}

We acknowledge the project "Effektiv konvertering af vedvarende energi vha. fastoxid-celler" under Det Strategiske Forskningsråds Programkomite for Energi og miljø, sagsnr. 2058-03-0014 for sponsoring this work.

\section{List of Symbols}

ASR Area specific resistance

CPO Catalytic partial oxidation

$\Delta V \quad$ Voltage drop

$E M F$ electro motive force

$F U$ Fuel utilization

$i V \quad$ Current voltage curves

LSM Lanthanum strontium manganite

OCV Open circuit voltage

$p \mathrm{O}_{2} \quad$ Partial pressure of oxygen

$\theta \quad$ Coverage

QMS Quadrupole mass spectrometer

SOFC Solid Oxide Fuel Cell

$\tau_{\text {deg }} \quad$ Cell voltage degradation rate

TPB Three-phase boundary

YSZ Yttria stabilized zirconia

\section{References}

[1] A . Hagen, R. Barfod, P.V. Hendriksen, Y.-L. Liu, S.Ramousse, J. Electrochem. Soc. 2006, 153(6), A1165.

[2] J. Staniforth, R. M. Ormerod, Catalysis Letters 2002, 81, 19-23.

[3] G. Goula, V. Kiousis, L. Nalbandian, I. V. Yentekakis, Solid State Ionics 2006, 177, 2119-2123.

[4] Y. Matsuzaki, Y. Baba, T. Sakurai, Solid State Ionics 2004, 174, 81-86.

[5] C. M. Finnerty, R. M. Ormerod, Journal of Power Sources 2000, 86, 390-394.

[6] T. Horita, K. Yamaji, T. Kato, H. Kishimoto, Y. Xiong, N. Sakai, M. E. Brito, H. Yokokawa, Journal of Power Sources 2005, 145, 133-138.

[7] Y. Lin, Z. Zhan, J. Liu, S. A. Barnett, Solid State Ionics 2005, 176, 1827-1835.

[8] K. Sasaki, K. Watanabe, K. Shiosaki, K. Susuki, Y. Teraoka, Journal of Electroceramics 2004, 13, 669-675.

[9] J.-H. Wang, M. Liu, Journal of Power Sources 2008, 176, 23-30.

[10] M. Mogensen, K. Kammer, Annu. Rev. Mater. Res. 2003, 33, 321-331.

[11] J.R. Rostrup-Nielsen, J. Sehested, J.K. Nørskov, Adv. Catal. 2002, 47, 65.

[12] K. Sasaki, K. Susuki, A. Iyoshi, M. Uchimura, N. Imamura, H. Kusaba, Y. Teraoka, H. Fuchino, K. Tsujimoto, Y. Uchida and N. Jingo, Journal of Electrochemical Society 2006, 153 (11), A2023-A2029.

[13] J. F. B. Rasmussen, A. Hagen, Journal of Power Sources 2009, 191, 534.

[14] S. Zha, Z. Cheng, M. Liu, Journal of the Electrochemical Society 2007, 154, B201-B206.

[15] J. R. Rostrup-Nielsen, J. B. Hansen, S. Helveg, N. Christiansen, A.-K. Jannasch, Appl. Phys., A 2006, 85, 427-430.

[16] M. Noponen, M. Halinen, J. Kiviaho, J. Saarinen, Journal of Fuel Cell Science and Technology 2006, 3 , 438-444.

[17] S. Ramousse, M. Menon, K. Brodersen, J. Knudsen, U. Rahbek, P. H. Larsen, ECS Transactions 2007, 7 (1), 317-327.

[18] M. Mogensen, P. V. Hendriksen, in "High Temperature Solid Oxide Fuel Cells. Fundamentals, Design and Applications", Elsevier Ltd, 2003.

[19] J. R. Rostrup-Nielsen, Catalytic Steam Reforming, Springer-Verlag, Berlin, 1984.

[20] J.-H. Koh, Y.-S. Yoo, J.-W. Park, H. C. Lim, Solid State Ionics 2002, 149, 157-166.

[21] Z. Cheng, S. Zha, M. Liu, Journal of Power Sources 2007, 172, 688-693.

[22] H. S. Bengaard, J. K. Nørskov, J. Sehested, B. S. Clausen, L. P. Nielsen, A. M. Molenbroek, J. R. RostrupNielsen, Journal of Catalysis 2002, 209, 365-384. 
Tables

Table 1: Fuel compositions, $\mathrm{FU}$ and $A \mathrm{SR}_{\text {cor }}$ values for the three $\mathrm{CH}_{4}$ tests.

\begin{tabular}{lllllll}
\hline Test & $\mathrm{H}_{2}(\%)$ & $\mathrm{CH}_{4}(\%)$ & $\mathrm{H}_{2} \mathrm{O}(\%)$ & $\mathrm{H}_{2} \mathrm{~S}(\mathrm{ppm})$ & $F U(\%)$ & $A_{S R_{\text {cor }}} *\left(\Omega \mathrm{cm}^{2}\right)$ \\
\hline 1 & 46 & 17 & 37 & $2,4,7,2$ & 60 & 0.19 \\
2 & 13 & 29 & 58 & 2 & 57 & 0.22 \\
3 & 13 & 29 & 58 & $4,9,7$ & 58 & 0.19 \\
\hline
\end{tabular}

* Obtained during initial fingerprint, see section 2.1

Table 2: The initial voltage drop $\left(\Delta V_{i n i}\right)$ and Degradation rate $\left(\tau_{\text {deg }}\right)$ of the $\mathrm{H}_{2}$ test [13] and the three $\mathrm{CH}_{4}$ tests (Test 1,2 and 3). $\mathrm{T}=850^{\circ} \mathrm{C} ; 1 \mathrm{Acm}^{-2}$.

\begin{tabular}{|c|c|c|c|c|c|c|c|c|}
\hline \multirow{3}{*}{$\begin{array}{l}\mathrm{H}_{2} \mathrm{~S} \text { conc. } \\
\text { (ppm) }\end{array}$} & \multirow{3}{*}{$\begin{array}{l}\mathrm{H}_{2} \text { test } \\
{[13]} \\
\Delta V_{i n i}\end{array}$} & \multicolumn{7}{|c|}{$\mathrm{CH}_{4}$ tests } \\
\hline & & \multicolumn{3}{|c|}{ Test 1} & \multicolumn{2}{|l|}{ Test 2} & \multicolumn{2}{|c|}{ Test 3} \\
\hline & & $\tau_{d e g}$ & $\Delta V_{i n i}$ & $\tau_{d e g}$ & $\Delta V_{i n i}$ & $\tau_{d e g}$ & $\Delta V_{i n i}$ & $\tau_{d e g}$ \\
\hline 2 & 75 & 0.1 & 79 & 0.7 & 73 & 1.1 & & \\
\hline 4 & 83 & 0.2 & 82 & 1.3 & & & 93 & 2.8 \\
\hline 7 & 87 & 0.2 & 107 & 1.2 & & & & \\
\hline 9 & 96 & 0.3 & & & & & & \\
\hline 18 & 98 & 0.3 & & & & & & \\
\hline 42 & 100 & 0.5 & & & & & & \\
\hline 100 & 108 & 0.7 & & & & & & \\
\hline
\end{tabular}

\section{Figure Captions}

Figure 1: Left: The test setup. Right: $\mathrm{H}_{2} \mathrm{~S}$ was added in two different ways, i.e. in steps of increasing concentrations with the cell at OCV (A) and in intervals with the cell under current load (B).

Figure 2: The cell voltage development. $\mathrm{H}_{2} \mathrm{~S}$ was added in concentration steps of $2 \mathrm{ppm}, 4 \mathrm{ppm}, 7 \mathrm{ppm}, 9 \mathrm{ppm}$, $20 \mathrm{ppm}$ and $24 \mathrm{ppm} . T=850^{\circ} \mathrm{C} ; \mathrm{OCV}, \mathrm{CH}_{4} / \mathrm{H}_{2} / \mathrm{H}_{2} \mathrm{O}$ fuel. Insert: $\mathrm{OCV}$ at different $\mathrm{H}_{2} \mathrm{~S}$ concentrations (see also values in the text).

Figure 3: The $\mathrm{CO} / \mathrm{CH}_{4}, \mathrm{CO}_{2} / \mathrm{CH}_{4}$ and $\left(\mathrm{CO}+\mathrm{CO}_{2}\right) / \mathrm{CH}_{4}$ ratios measured at fuel outlet by QMS as function of $\mathrm{H}_{2} \mathrm{~S}$ concentration in the fuel. $T=850^{\circ} \mathrm{C} ; \mathrm{OCV}, \mathrm{CH}_{4} / \mathrm{H}_{2} / \mathrm{H}_{2} \mathrm{O}$ fuel.

Figure 4: The calculated $\mathrm{CH}_{4}$ conversion, based on the measured OCV. $T=850^{\circ} \mathrm{C} ; \mathrm{OCV}$, insert: S-coverage as calculated according to [19].

Figure 5: The cell voltage developments. Black: test 1 , green: test 2 , and blue: test 3 . The letters a, b, c and d indicate where the varying concentrations of $\mathrm{H}_{2} \mathrm{~S}$ were added to the fuel. The horizontal arrows show the periods under OCV due to maintenance work in the lab. The insert illustrates the initial voltage drop and the degradation rate under $4 \mathrm{ppm} \mathrm{H}_{2} \mathrm{~S}$ addition in test $1 . T=850^{\circ} \mathrm{C} ; 1 \mathrm{Acm}^{-2}, \mathrm{CH}_{4} / \mathrm{H}_{2} / \mathrm{H}_{2} \mathrm{O}$ fuel (compositions see Table 1). Figure 6: The calculated $F U$ for the cells in test 1 and $3 . T=850^{\circ} \mathrm{C} ; 1 \mathrm{Acm}^{-2}$.

Figure 7: The initial poisoning rates (50\% voltage drop) compared to the initial recovery rates (50\% voltage increase) as function of $\mathrm{H}_{2} \mathrm{~S}$ concentration. Top: $\mathrm{CH}_{4}$ tests; Bottom: $\mathrm{H}_{2}$ test [13]. $T=850^{\circ} \mathrm{C} ; 1 \mathrm{Acm}^{-2}$.

Figure 8: The internal resistance development (impedance spectra), when $2 \mathrm{ppm}_{2} \mathrm{~S}$ was added in test 2. $T=$ $850^{\circ} \mathrm{C} ; 1 \mathrm{Acm}^{-2}$. 
Fig. 1

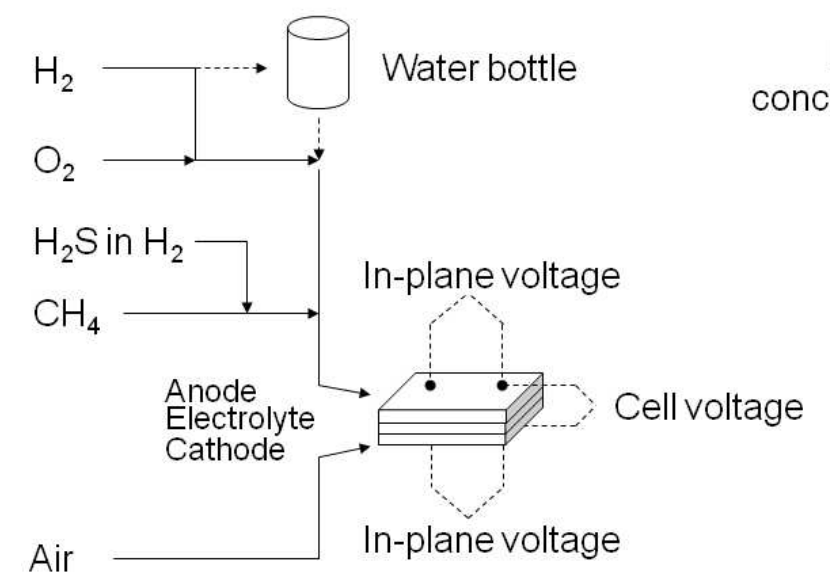

$\mathrm{H}_{2} \mathrm{~S}$

Left: The test setup. Right: $\mathrm{H}_{2} \mathrm{~S}$ was added in two different ways, i.e. in steps of increasing concentrations with the cell at OCV (A) and in intervals with the cell under current load (B). $254 \times 190 \mathrm{~mm}(96 \times 96 \mathrm{DPI})$ 
The cell voltage development. $\mathrm{H}_{2} \mathrm{~S}$ was added in concentration steps of $2 \mathrm{ppm}, 4 \mathrm{ppm}, 7 \mathrm{ppm}, 9$ ppm, $20 \mathrm{ppm}$ and $24 \mathrm{ppm}$. $\mathrm{T}=850{ }^{\circ} \mathrm{C} ; \mathrm{OCV}, \mathrm{CH}_{4} / \mathrm{H}_{2} / \mathrm{H}_{2} \mathrm{O}$ fuel. Insert: OCV at different $\mathrm{H}_{2} \mathrm{~S}$ concentrations (see also values in the text). $254 \times 190 \mathrm{~mm}(96 \times 96 \mathrm{DPI})$ 
1

2

3

4

5

6

7

8

9

10

11

12

13

14

15

16

17

18

19

20

21

22

23

24

25

26

27

28

29

30

31

32

33

34

35

36

37

38

39

40

41

42

43

44

45

46

47

48

49

50

51

52

53

54

55

56

57

58

59

60

Fig. 3

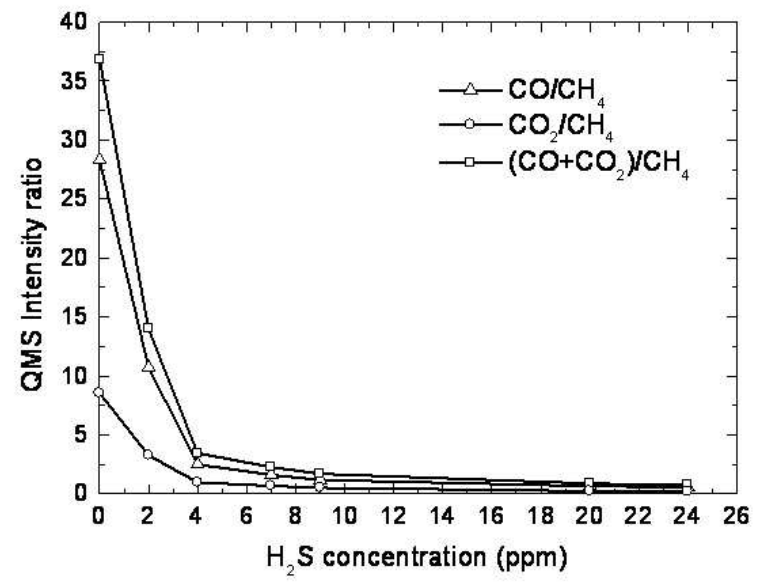

The $\mathrm{CO} / \mathrm{CH}_{4}, \mathrm{CO}_{2} / \mathrm{CH}_{4}$ and $\left(\mathrm{CO}+\mathrm{CO}_{2}\right) / \mathrm{CH}_{4}$ ratios measured at fuel outlet by QMS as function of $\mathrm{H}_{2} \mathrm{~S}$ concentration in the fuel. $\mathrm{T}=850{ }^{\circ} \mathrm{C} ; \mathrm{OCV}, \mathrm{CH}_{4} / \mathrm{H}_{2} / \mathrm{H}_{2} \mathrm{O}$ fuel.

$254 \times 190 \mathrm{~mm}(96 \times 96 \mathrm{DPI})$ 
Fig. 4

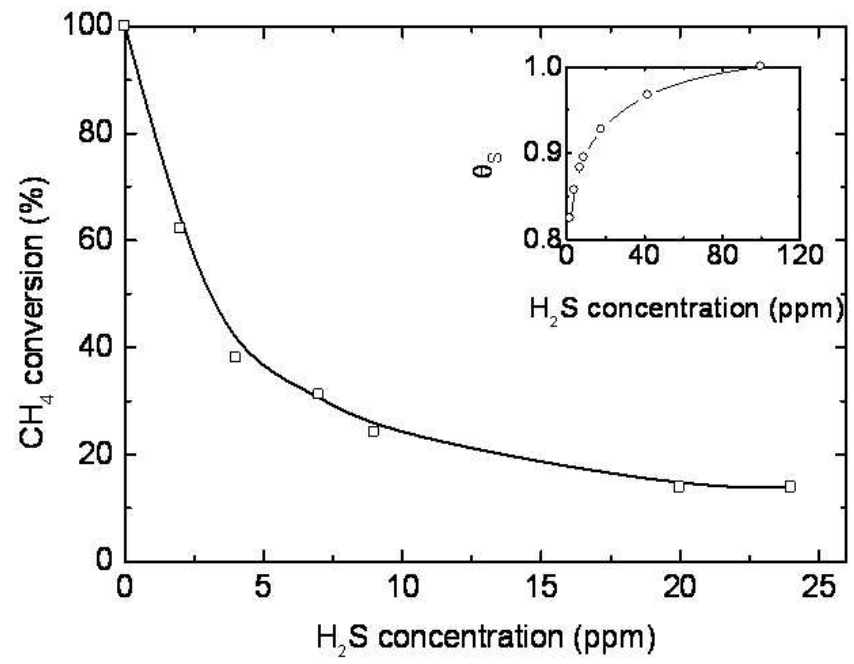

The calculated $\mathrm{CH}_{4}$ conversion, based on the measured $\mathrm{OCV} . \mathrm{T}=850{ }^{\circ} \mathrm{C} ; \mathrm{OCV}$, insert: S-coverage as calculated according to [19].

$254 \times 190 \mathrm{~mm}(96 \times 96 \mathrm{DPI})$ 


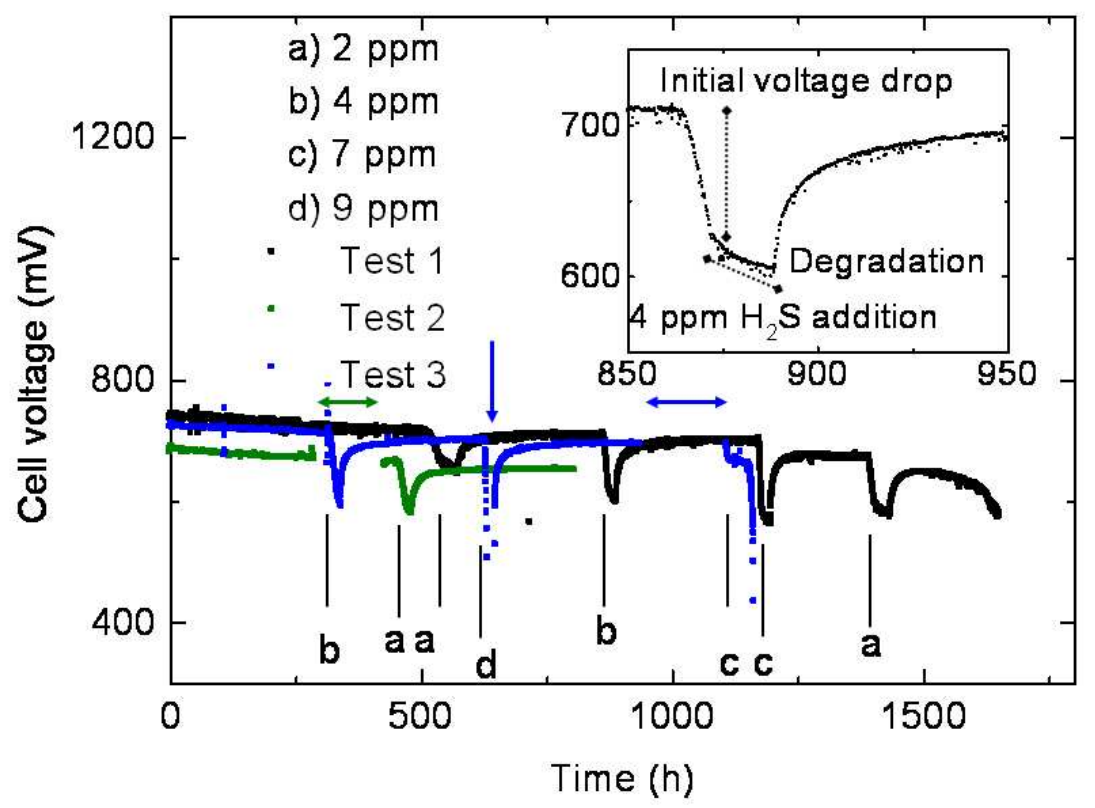

The cell voltage developments. Black: test 1 , green: test 2 , and blue: test 3 . The letters $a, b, c$ and $d$ indicate where the varying concentrations of $\mathrm{H}_{2} \mathrm{~S}$ were added to the fuel. The horizontal arrows show the periods under OCV due to maintenance work in the lab. The insert illustrates the initial

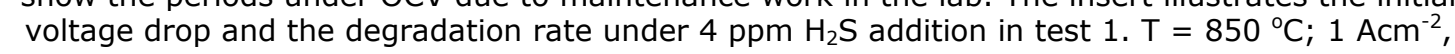
$\mathrm{CH}_{4} / \mathrm{H}_{2} / \mathrm{H}_{2} \mathrm{O}$ fuel (compositions see Table 1). $254 \times 190 \mathrm{~mm}(96 \times 96 \mathrm{DPI})$ 
The calculated FU for the cells in test 1 and $3 . \mathrm{T}=850^{\circ} \mathrm{C} ; 1 \mathrm{Acm}^{-2}$. $254 \times 190 \mathrm{~mm}(96 \times 96 \mathrm{DPI})$ 
Fig. 7

The initial poisoning rates (50\% voltage drop) compared to the initial recovery rates ( $50 \%$ voltage increase) as function of $\mathrm{H}_{2} \mathrm{~S}$ concentration. Top: $\mathrm{CH}_{4}$ tests; Bottom: $\mathrm{H}_{2}$ test [13]. $\mathrm{T}=850{ }^{\circ} \mathrm{C} ; 1$ $\mathrm{Acm}^{-2}$.

$254 \times 190 \mathrm{~mm}(96 \times 96 \mathrm{DPI})$ 
Fig. 8

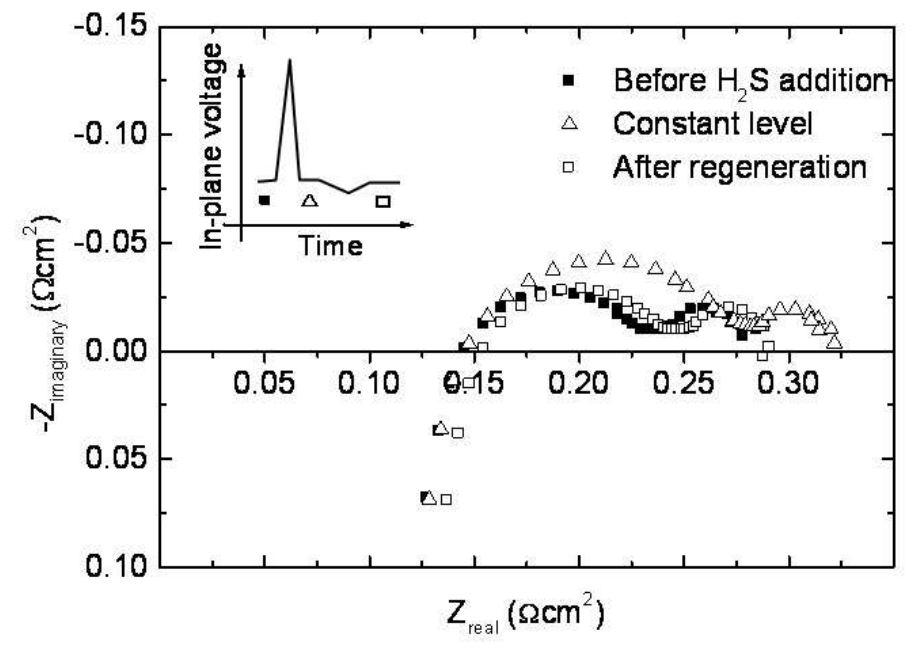

The internal resistance development (impedance spectra), when $2 \mathrm{ppm} \mathrm{H}_{2} \mathrm{~S}$ was added in test 2. T $=850{ }^{\circ} \mathrm{C} ; 1 \mathrm{Acm}^{-2}$. $254 \times 190 \mathrm{~mm}(96 \times 96 \mathrm{DPI})$ 